\title{
Challenges in using soil carbon modelling in LCA of agricultural products - the devil is in the detail
}

\author{
Katri Joensuu $^{1}$ (D) Karoliina Rimhanen ${ }^{1} \cdot$ Hannele Heusala ${ }^{1} \cdot$ Merja Saarinen $^{2} \cdot$ Kirsi Usva $^{2} \cdot$ Ilkka Leinonen $^{1} \cdot$ \\ Taru Palosuo ${ }^{1}$
}

Received: 25 September 2020 / Accepted: 20 August 2021 / Published online: 1 September 2021

(c) The Author(s) 2021

\begin{abstract}
Purpose Currently, there is no consensus on how the impacts of land use on the soil organic carbon (SOC) stocks would be best quantified within life cycle assessments (LCA) of agricultural products. The impacts of different decisions were tested within a model-based assessment of soil carbon changes on the life cycle global warming impact for spring wheat produced in two example regions in Finland (Southwest Finland and Northern Savonia) on mineral fields.

Methods Global warming impact for spring wheat was assessed, including $\mathrm{CO}_{2}$ emissions due to the SOC change. The SOC change assessment was made with the soil carbon model Yasso07. The effects of assumptions on land use history were tested, i.e. the initialisation of the model and time horizon of the analysis (20 or 100 years) on the SOC change estimates. Other greenhouse gas emissions contributing to the global warming impact of spring wheat production were assessed using general LCA methodology taking into account the greenhouse gas emissions caused by the production of input materials and fuels, as well as direct and indirect $\mathrm{N}_{2} \mathrm{O}$ emissions from the soil due to fertilising and the decomposition of crop residues and organic matter, nitrogen leaching and volatilisation and lime application.

Results and discussion The selection of the model initialisation method and timeframe remarkably affected the SOC change estimates. The global warming impact of wheat production, without accounting for SOC changes, was 0.68 and $0.89 \mathrm{~kg}$ $\mathrm{CO}_{2}$-eq/kg yield in Southwest Finland and Northern Savonia, respectively. The impact of SOC stock changes on the total global warming impact varied from -4 to $5 \%$ in Southwest Finland and from 5 to $21 \%$ in Northern Savonia, depending on the assumptions used to initialise the model or the timeframe applied in the analysis. Adding a cover crop as a means to increase the SOC stock removed between -67 and $-26 \%$ of the total global warming impact in both regions.

Conclusions It is essential that all the decisions made in the analysis are transparently reported and communicated. The choice of assumptions regarding the reference state, model initialisation and time horizon of the assessment period should be made based on the scope and goal definition of the LCA study.
\end{abstract}

Keywords Global warming · Life-cycle assessment (LCA) · Soil carbon modelling · Wheat production · Sustainability · Carbon footprint

\section{Introduction}

Life-cycle assessment (LCA) is a well-established tool to quantify the environmental impacts of products, including

Communicated by Thomas Jan Nemecek

Katri Joensuu

katri.joensuu@luke.fi

1 Natural Resources Institute Finland (Luke), Latokartanonkaari 9, 00790 Helsinki, Finland

2 Natural Resources Institute Finland (Luke), Tietotie 4, 31600 Jokioinen, Finland greenhouse-gas (GHG) emissions, and the contribution of the product to the $\mathrm{CO}_{2}$ mitigation (Guinée and Heijungs 2005; ISO 14040:2006; ISO 14044:2006). Mostly, LCA is used for guiding and supporting decision-making, e.g. when making choice between two products or production systems or planning improvements of the systems or policies (European Commission, Joint Research Centre 2010). LCA has increasingly been used to study the impacts of food 
products and agricultural systems (Nijdam et al. 2012; Clune et al. 2017; Moberg et al. 2019). Fundamental principles of LCA include focus on environmental impacts, comprehensiveness of attributes or aspects of natural environment, human health and resources and transparency of analysis (ISO 14040:2006; ISO 14044:2006).

Global climate change driven by human activity (Pachauri et al. 2014) has made global warming a key category of LCA (European Commission, Joint Research Centre 2010). In the land-use based sectors, this has put special focus on integrating soils in LCA, as they are important terrestrial carbon stocks, acting either as a carbon sink or a source of atmospheric $\mathrm{CO}_{2}$ (Paustian et al. 2016; Griscom et al. 2017).

Carbon dynamics in soils is affected by land use (LU) as well as various land management (LM) measures (e.g. ploughing) within different land use types but also by climatic conditions and plant litter input driven by ecosystem production. There are high expectations that soils would sequester a considerable amount of carbon and thereby offset global anthropogenic GHG emissions (Minasny et al. 2017). It has been estimated that, worldwide, cropland soils could annually sequester between 0.9 and $1.85 \mathrm{Pg}$ of $\mathrm{C}$, which would be $26-53 \%$ of the target of the 4 p1000 Initiative launched at COP21 (Zomer et al. 2017). Increasing the amount of soil organic carbon (SOC) also improves soil fertility and has thereby important co-benefits to food security (Lal 2004). However, the success of mitigating climate change through increasing the SOC stocks has been questioned in some studies (Schlesinger and Amundson 2019).

Despite the current nature of the SOC management for climate change mitigation, there is currently no consensus on how the impacts of land management and LUCs on SOC stocks would be best quantified within LCA (Goglio et al. 2015). A recent technical standard for estimates of greenhouse gas emissions and carbon footprints of products (ISO 14067:2018) states that SOC changes due to land use and land use changes should be included in carbon footprint studies. However, as the standard does not define any specific impact assessment methods to apply. Despite the lack of consensus, recommendations have been given for example by UNEP-SETAC. Their guidelines (Koellner et al. 2013) are largely based on the framework of Mila i Canals et al. (2007). In this approach, the assessment is based on a comparison of the SOC stock level during production to a reference land use situation, which is defined as the constant SOC stock level in a biome-dependent natural state. The IPCC (The Intergovernmental Panel on Climate Change) (2006) gives three optional approaches in estimating SOC changes in national greenhouse gas inventories: the 'Tier 1' approach corresponds to the simplest default methods; Tier 2 employs country-specific static parameters, where certain landuse types relate to some default SOC stock values. The most complex and recommended Tier 3 methods apply detailed measurements and/or modelling. The modelling can include, for example, crop growth models that take into account management effects such as harvesting and fertilization (Smith et al. 2020).

Goglio et al. (2015) reviewed different methods to account for SOC in agricultural LCA, including measurements and dynamic crop-climate-soil models, simple carbon models and emission factors. They concluded that the selection of the method should be consistent with the objectives and scale of the LCA. Additionally, data availability affects the selection of the method. In their ranking of the preference of SOC accounting methods, models were preferred to measurements. Due to inherently high spatial variability of SOC stocks and costly measurements, there is seldom enough measured data available from the studied systems to allow for the assessment of SOC changes (Heikkinen et al. 2020). Furthermore, there are only very few long-term trials available where measured SOC stocks would be available at the beginning of the experiments (Sanderman and Baldock 2010). Different modelling approaches are already widely applied in assessing the SOC changes in agriculture and forestry (see, e.g. Peltoniemi et al. 2007; Riggers et al. 2019).

This study hypothesises that model-based SOC assessments in LCA studies involve large uncertainties that are due to implicit and explicit assumptions made within the modelling process. This is because it is not self-evident how dynamic variables such as SOC stock changes should be converted into emission indicators describing the consequences of human activities. Assumptions within the SOC modelling process related to especially the initialisation of the SOC stocks at the beginning of simulations, reflecting the assumptions on land use history, (Foereid et al. 2012; Palosuo et al. 2016), as well as the timeframe considered in the assessment (Petersen et al. 2013) are known to have great effects on the results.

The overall goal of this paper is to contribute to the recent discussion on how to best take the SOC changes into account in assessing the global warming impact category in the LCA studies of agricultural products. Spring wheat (Triticum aestivum L.) production was used on mineral soils in two case study regions in Finland as simplified example cases to response to the following two questions representing possible goals for an LCA study:

Q1: What is the life cycle global warming impact of wheat production in the case regions, including the SOC change?

Q2: What is the life cycle global warming impact of an alternative management option, i.e. to add cover crops into the wheat production system? 
A model-based SOC change assessment was applied together with other GHG emission estimates within the LCA framework to assess the global warming impact of wheat production. The objective of this study was to demonstrate the impacts of assumptions and decisions related to land use history and the time frame of the analysis made within the SOC assessment process on the overall global warming results and conclusions made.

\section{Material and methods}

\subsection{Case regions}

The spring wheat production on mineral soil was assessed in two geographical regions in Finland: Southwest Finland and Northern Savonia (Fig. 1). Agricultural production in these

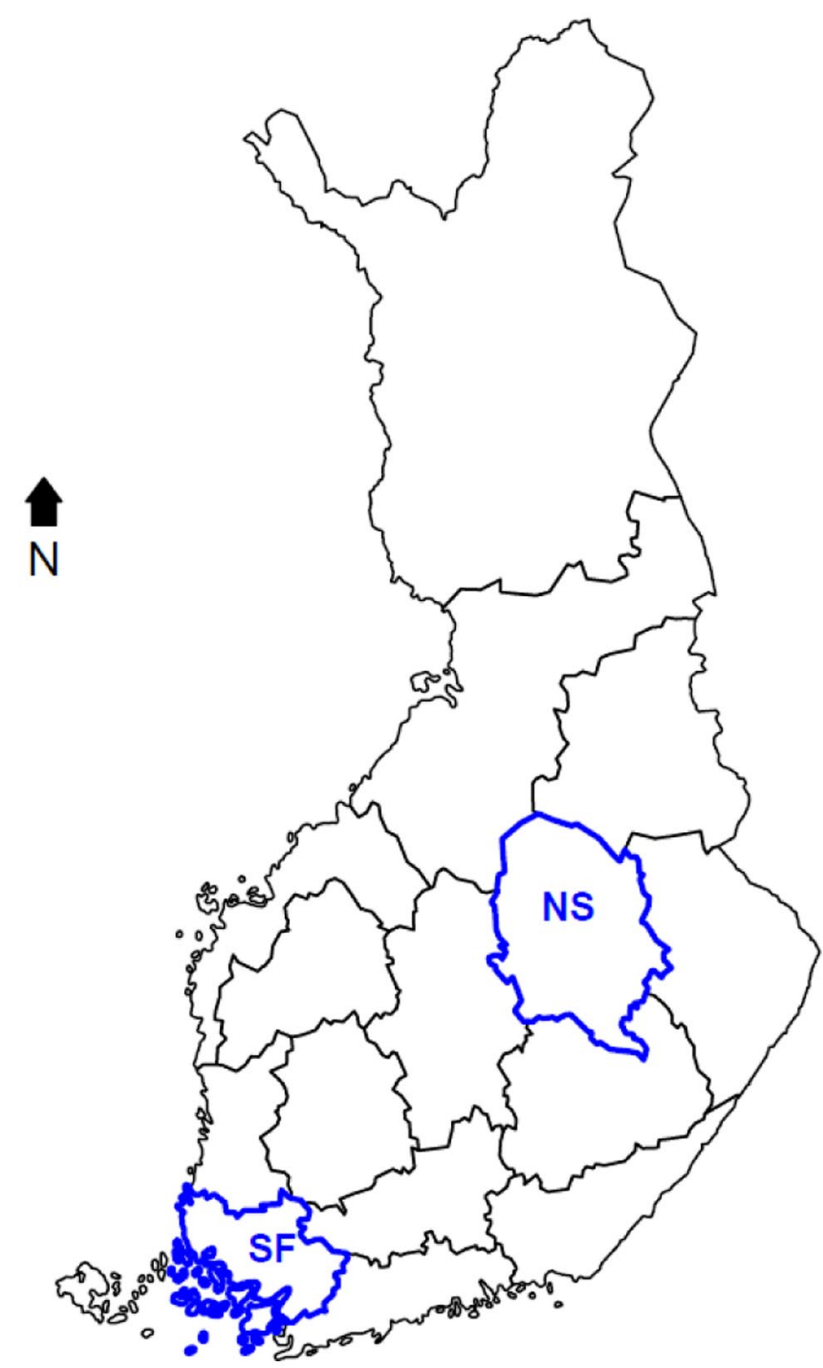

Fig. 1 Map of the case regions. NS depicts Northern Savonia, and SF depicts Southwest Finland
Table 1 Long-term average climate data (1961-2018) of the case study regions calculated from the gridded weather data provided by the Finnish Meteorological Institute, as described in Palosuo et al. (2016)

\begin{tabular}{lll}
\hline & $\begin{array}{l}\text { Southwest } \\
\text { Finland }\end{array}$ & $\begin{array}{l}\text { Northern } \\
\text { Savonia }\end{array}$ \\
\hline Annual precipitation $(\mathrm{mm})$, & 636 & 633 \\
Annual mean temperature $\left({ }^{\circ} \mathrm{C}\right)$ & 5.1 & 2.8 \\
Annual temperature amplitude $\left({ }^{\circ} \mathrm{C}\right)$ & 12.2 & 14.4 \\
\hline
\end{tabular}

regions differ: in Northern Savonia, the production is mainly based on dairy and cattle; of the total agricultural land, the proportion of grass leys is $58 \%$ of the total agricultural land and $31 \%$ of cereals, whereas in Southwest Finland the share of cereal crops is $76 \%$, and the share of grass leys is only 10\% (Luke 2020a). The long-term climate variables for the regions are given in Table 1.

\subsection{Global warming calculation methods, functional unit and system boundaries}

The life cycle assessment (LCA) methodology (ISO 14040:2006; ISO 14044:2006) was applied to acquire an overview of the climate impact of spring wheat in two regions and answer the research questions $(\mathrm{Q} 1$ and $\mathrm{Q} 2)$. The functional unit of the study was $1 \mathrm{~kg}$ of spring wheat at the farm gate, and the assessment covered all emissions until the farm gate (Fig. 2). The total GHG emissions were presented in terms of $\mathrm{CO}_{2}$-equivalents $\left(\mathrm{CO}_{2}\right.$-eq) that indicate the systems potential contribution to global warming. Conversion of $\mathrm{N}_{2} \mathrm{O}$ and $\mathrm{CH}_{4}$ emissions to $\mathrm{CO}_{2}$-equivalents was done using the IPCC characterisation factors for 100 years (Foster et al. 2007) $\left(\mathrm{CO}_{2}=1\right.$, biogenic $\mathrm{CH}_{4}=34$, fossil $\mathrm{CH}_{4}=36.75, \mathrm{~N}_{2} \mathrm{O}=298$ ). Emissions from the production system were compared with the mean annual soil carbon sink over 100 years (Cowie et al. 2007). Also, a commonly applied assumption was made that the climate impact of a negative $\mathrm{CO}_{2}$ emission is equal in magnitude and opposite in sign to the impact to an equivalent positive $\mathrm{CO}_{2}$ emission.

GHG emissions caused by the production of the cultivation inputs (seeds, fertiliser, lime and fuels) were included, as well as direct emissions caused by fuel use at machinery work in the fields and grain drying. $\mathrm{N}_{2} \mathrm{O}$ emissions from the soil due to fertilising and decomposition of crop residues and organic matter and indirect $\mathrm{N}_{2} \mathrm{O}$ emissions from nitrogen leaching and other nitrogen air emissions were calculated by applying the instructions of the IPCC (Eggleston et al. 2006), which are also applied in the GHG inventory of Finland (Statistics Finland 2019). Similarly, $\mathrm{CO}_{2}$ emissions from lime application were calculated based on IPCC (2006) instructions. The impacts of SOC changes due to land use 
Fig. 2 System boundary of the studied spring wheat system

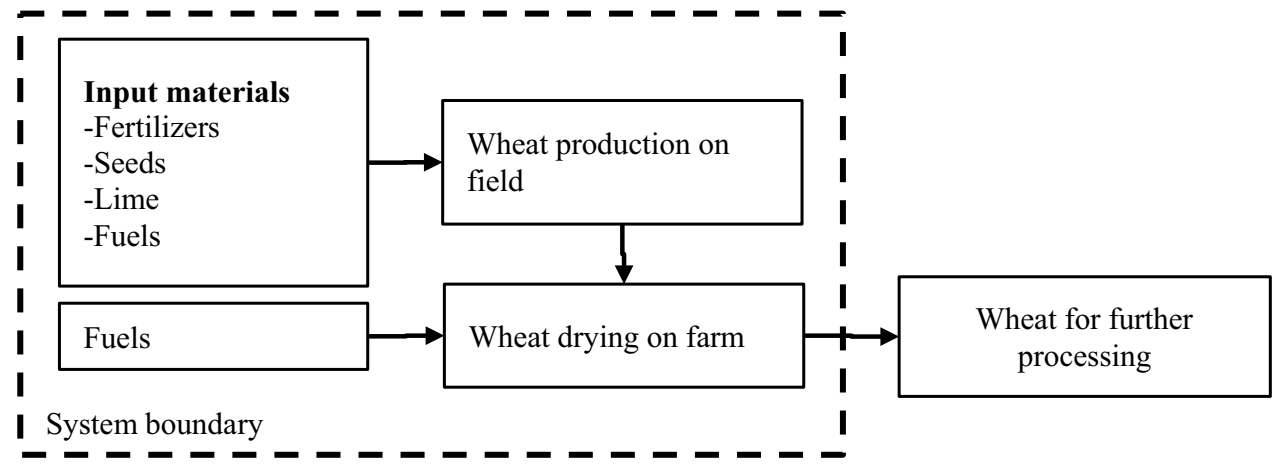

were included as alternative implementations, as described in the sections below. The emission categories, methods and key emission factors used are shown in Table 2.

\subsubsection{SOC change calculations and reference state}

To calculate the SOC changes of the mineral soils, the dynamic soil carbon model Yasso07 model was used (Tuomi et al. 2009). The model is widely tested and used, for example, in the GHG inventories of several countries, e.g. Finland (Statistics Finland 2019) and in earth system models (e.g. Thum et al. 2020). Yasso07 describes the decomposition of organic matter using information on weather and litter quality. SOC in the model is divided in five compartments (A, acid soluble; W, water soluble; E, ethanol soluble; N, non-soluble; and H, humus). Litter input is divided into the first four compartments according to its chemical quality, whereas humus is simulated to form as a result of the decomposition of other compounds. All five compartments are decomposing at their own rates, and these rates are affected by the climate conditions. Mass flow parameters determine the shares of decomposed SOC that flow into the other compartments and the shares that are released into the atmosphere as $\mathrm{CO}_{2}$. Detailed model description is available, for example, in Tuomi et al. (2011).

The model has been calibrated using large datasets of decomposition of various litter types and observation of soil carbon stocks in different climatic zones. Here the original parameterisation of the model was used (Table 3 in Tuomi et al. 2009), which has successfully been applied in the agricultural model tests (e.g. Karhu et al. 2012; Riggers et al. 2019) and in soil carbon assessments of cropland and grassland soils (Palosuo et al. 2016). The simulated estimates using this parameter set represented soil layers down to a depth of $1 \mathrm{~m}$.

Table 2 Emission sources, methods and the emission factors used in the study

\begin{tabular}{|c|c|c|}
\hline Emission source & Method/data source & Emission factors \\
\hline \multicolumn{3}{|l|}{ SOC change as $\mathrm{CO}_{2}$} \\
\hline Mineral soils $\left(\mathrm{CO}_{2}\right)$ & IPCC Tier 3, Yasso07 (Tuomi et al. 2009) & - \\
\hline \multicolumn{3}{|l|}{ Production of input materials and fuels } \\
\hline Mineral fertiliser & Yara (2015) & $3.6 \mathrm{~kg} \mathrm{CO} 2 \mathrm{eq} / \mathrm{kg} \mathrm{N}$ \\
\hline Limestone & Nordkalk (2006) & $0.0116 \mathrm{~kg} \mathrm{CO}{ }_{2} \mathrm{eq} / \mathrm{kg}$ \\
\hline Seeds & Saarinen et al. (2014) & $\begin{array}{l}0.4 \mathrm{~kg} \mathrm{CO} \mathrm{eq}_{2} / \mathrm{kg} \text { (wheat) } \\
0.5 \mathrm{~kg} \mathrm{CO} \mathrm{CO}_{2} \mathrm{eqg} \text { (ley crops) }\end{array}$ \\
\hline Diesel & Ecoinvent 3 & $0.53 \mathrm{~kg} \mathrm{CO}{ }_{2} \mathrm{eq} / \mathrm{kg}$ \\
\hline Emissions during field production & IPCC Tier 1 & \\
\hline Direct $\mathrm{N}_{2} \mathrm{O}$ from fertilisation & IPCC (2006) & $0.016) \mathrm{kg} \mathrm{N}_{2} \mathrm{O} / \mathrm{kg}$ fertiliser $\mathrm{N}$ \\
\hline Indirect $\mathrm{N}_{2} \mathrm{O}$ from $\mathrm{N}$ leaching & IPCC (2006) & $0.003 \mathrm{~kg} \mathrm{~N}_{2} \mathrm{O} / \mathrm{kg}$ fertiliser $\mathrm{N}$ \\
\hline Indirect $\mathrm{N}_{2} \mathrm{O}$ from $\mathrm{N}$ volatilisation as $\mathrm{NH}_{3}$ and $\mathrm{NOx}$ & IPCC (2006) & $0.002 \mathrm{~kg} \mathrm{~N}_{2} \mathrm{O} / \mathrm{kg}$ fertiliser $\mathrm{N}$ \\
\hline $\mathrm{N}_{2} \mathrm{O}$ from crop residues & IPCC (2006) & $0.016 \mathrm{~kg} \mathrm{~N}_{2} \mathrm{O} / \mathrm{kg}$ crop residue $\mathrm{N}$ \\
\hline $\mathrm{N}_{2} \mathrm{O}$ from organic matter & IPCC (2006) & $13 \mathrm{~kg} \mathrm{~N}_{2} \mathrm{O} / \mathrm{ha}$ (for annual crops) \\
\hline Liming & IPCC (2006) & $0.44 \mathrm{~kg} \mathrm{CO}_{2} / \mathrm{kg}$ \\
\hline Fuel use & $\begin{array}{l}\text { Lipasto database (VTT Technical Research Centre of } \\
\text { Finland 2017), fuel consumption of different field } \\
\text { operations based on Mikkola and Ahokas (2009) and } \\
\text { Grönroos and Voutilainen (2001) }\end{array}$ & $\begin{array}{l}2.724 \mathrm{~kg} \mathrm{CO}_{2} \text {-eq/l diesel } \\
\text { (farm tractor), } \\
2.673 \mathrm{~kg} \mathrm{CO} \text {-eq/l diesel (combine } \\
\text { harvester) }\end{array}$ \\
\hline
\end{tabular}


Table 3 Estimated mean carbon inputs into soils from plant litter and manure

\begin{tabular}{|c|c|c|}
\hline & Southwest Finland & Northern Savonia \\
\hline & $\begin{array}{l}\text { Total C input } \\
\left(\mathrm{kg} \mathrm{C} \mathrm{ha}^{-1} \mathrm{a}^{-1}\right)\end{array}$ & $\begin{array}{l}\text { Total C input } \\
\left(\mathrm{kg} \mathrm{C} \mathrm{ha}^{-1} \mathrm{a}^{-1}\right)\end{array}$ \\
\hline Forest (until 1900) ${ }^{1}$ (Q1) & 4614 & 4614 \\
\hline Regional average input used in initialisations $(\mathrm{Q} 1)^{2}$ & 2915 & 2726 \\
\hline Wheat average input used in initialisation $(\mathrm{Q} 2)^{2}$ & 2826 & 2485 \\
\hline $\begin{array}{l}\text { Wheat average input used during modelling period }{ }^{3} \text { (Q1 } \\
\text { and Q2) }\end{array}$ & 3005 & 2436 \\
\hline Clover cover crop during modelling period $(\mathrm{Q} 2)^{4}$ & 1388 & 1388 \\
\hline
\end{tabular}

${ }^{1}$ Akujärvi et al. (2014)

${ }^{2}$ Crop production statistics (Luke Statistics 2020a) and statistics on animal numbers (Luke Statistics 2020c) between 1999 and 2018

${ }^{3}$ Crop production statistics (Luke Statistics 2020b) between 2013 and 2018

${ }^{4}$ Känkänen et al. (2003)
The impacts of wheat production and alternative management on SOC stocks were assessed in reference to the stocks at the beginning of the simulation period, i.e. the SOC stock at the end of simulations were compared with the stock at the beginning. This compares to the approach of experimental trials where observations of the SOC stocks are made and changes in time are calculated. Annual SOC change estimates for Q1 were calculated as a mean annual trend in between the start and end point of the assessment period. For the impact of a management change (Q2), the SOC change was estimated for the alternative and baseline management options in the same way, and their difference was considered a result of the management change.

\subsection{Data and data sources}

\subsubsection{Wheat production data}

The wheat production data was selected to represent average production in the two regions under analysis. Therefore, the data was obtained from national statistics, national fertilisation and liming recommendations and other relevant literature sources. Spring wheat regional mean yields between 2013 and 2018, $3339 \mathrm{~kg} \mathrm{DM} / \mathrm{ha}$ in Southwest Finland, and $2706 \mathrm{~kg} \mathrm{DM} / \mathrm{ha}$ in Northern Savonia were obtained from Luke yield statistics (Luke Statistics 2020a). The fertilisation level was estimated to be $110 \mathrm{~kg} \mathrm{~N} / \mathrm{ha}$, based on the fertilisation instructions of the Finnish Cereal Committee (VYR 2011), and the lime use (916 kg/ha/year in Southwest Finland and $817 \mathrm{~kg} / \mathrm{ha}$ in Northern Savonia) was estimated according to the soil type specific instructions of the Nordkalk company (2019) based on the regional distribution of soil types. The share of the direct seeded field area in cereal production was estimated to be $12.8 \%$ on both areas (Luke 2016). Estimates of fuel consumption in field machinery work were based on Mikkola and Ahokas (2009) and
Grönroos and Voutilainen (2001). The fuel consumption of field ploughing differs between soil types (clay, coarse mineral and organic soils), and the regional share of different mineral soil types was obtained from the statistics of the Finnish soil fertility testing service (Luke Statistics 2020b). The share of clay soils was $81 \%$ and $19 \%$, and the share of coarse mineral soils was $19 \%$ and $81 \%$ in Southwest Finland and Northern Savonia, respectively.

The change in crop management considered in Q2 was the inclusion of a cover crop (red clover [Trifolium pratense L.]) in the production system. Above ground and below ground biomasses of the clover were estimated, based on Känkänen et al. (2003), to be $910 \mathrm{~kg} \mathrm{DM} / \mathrm{ha}$ and $1138 \mathrm{~kg}$ $\mathrm{DM} / \mathrm{ha}$, respectively. The cover crop was not assumed to be utilised as a co-product, and thus there is no need for the allocation of impacts between products.

\subsubsection{C input data needed for SOC change assessment}

The Yasso07 model requires carbon input information, both in terms of amount and chemical quality. The annual litter estimates from the wheat production systems included above-ground (wheat straw and stubble, above-ground biomass of red clover) and underground (roots) plant litter, rhizodeposition and manure. The carbon input from plants was estimated based on the average wheat grain yields of the study regions (Luke Statistics 2020a) and plant specific allocation factors using the approach developed by Bolinder et al. (2007) with country-specific factors (dry matter contents, harvest indexes, shoot to root dry biomass ratios and turnover rates of the root biomass), as presented in Table 1 of Palosuo et al. (2016). The chemical quality of plant residues was estimated with proportions of AWEN fractions following parameters gathered to Table 2 in Palosuo et al. (2016). Manure input used in the historical land-use options for model initialisation was estimated based on animal 
numbers (Luke Statistics 2020c) and the average annual excretion of volatile solids in manure per head of species (Statistics Finland 2019).

\subsubsection{Climate data}

The climate variables needed for the use of Yasso07 model include annual precipitation $(\mathrm{mm})$, annual mean temperature $\left({ }^{\circ} \mathrm{C}\right)$ and the annual temperature amplitude $\left({ }^{\circ} \mathrm{C}\right)$ which describes intra-annual variation in temperature. Climatic data was obtained from the Finnish Meteorological Institute, as described by Palosuo et al. (2016), representing the average of the selected regions during the time period 1961-2018 (Table 1).

\subsection{Testing key assumptions in SOC change estimation}

The key assumptions in the SOC change calculations and their impacts on the SOC change estimates were demonstrated with simple tests by conducting the calculations with alternative assumptions. Rather than providing a sensitivity analysis for the input data or model parameters, the aim was to show how much these assumptions may affect the overall assessment. The assumptions tested were (1) assumptions on land use history implemented via soil model initialisation and (2) time horizon, i.e. the length of the period during which the changes are occurring. Sensitivity of the model results to the litter inputs are presented in the Supplementary material.

\subsubsection{Assumptions on land use history or initial SOC stock status}

To acknowledge the long-term dynamics of SOC and the impacts of possible underlying long-term trends in the stocks on LCA results, two different alternatives were tested for the land use history or the SOC stock status at the beginning of the simulations for the case regions $(\mathrm{Q} 1)$ :

11 assumed the soil to be in a steady state with the recent regional average field use. The average $\mathrm{C}$ input (Table 3) was calculated for the study regions over the previous 20 years, 1999-2018, and manure input from animal production of the region was included as described in Sect. 2.3.2. The steady-state assumption is a commonly used method for initiating the SOC stocks of the Yasso07 model (Tuomi et al. 2011).

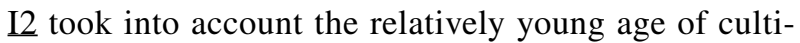
vated areas in Finland. The simulations were started from 1900 using the estimated SOC stock of forests $(160 \mathrm{Mg}$ $\mathrm{C} \mathrm{ha}^{-1}$ following Akujärvi et al. (2014) and pre-running the model for a period of 118 years with average agricul- tural plant residue and manure input, as described for I1. Consequently, the SOC stock is not in the steady state with agricultural inputs as in I1, but the stock is steadily decreasing from year to year, as it takes hundreds of years to reach the new equilibrium with the applied Yasso parameters. This approach is applied, for example, in the Finnish National Greenhouse Gas Inventory for cropland soils (Statistics Finland 2019).

For the impact of the management change (Q2), the SOC stock in the beginning of the simulations does not affect the SOC stock change estimates that are calculated as a mean difference between the SOC stocks of two land management options initiated similarly. This is because within the simulations of the two management options, the decomposition pattern of the initial SOC is identical.

\subsubsection{Time horizon}

The impact of different time horizons were tested for both Q1 and Q2 by calculating the SOC changes for the following simulation periods: T20, accounting for the mean annual SOC change over 20 years, and T100, considering the mean annual SOC change over 100 years.

To identify the impact of 1 year of wheat production, the total SOC change is divided by the length of the simulation period. A period of 20 years has been used, for example, in the IPCC assessments for LUCs (Eggleston et al. 2006). On the other hand, a period of 100 years has been used particularly for cooler climate conditions (Petersen et al. 2013). Its use has been suggested as the SOC dynamics is slow, although it is unlikely that the management would remain the same over several decades.

\section{Results}

\subsection{SOC dynamics and change estimates}

\subsubsection{Q1: SOC change under ongoing land use}

The projected development of the SOC stocks and, thereby, also the estimated SOC stock change essentially depended on the assumptions on the land use history and applied climate data, i.e. the way the soil carbon model was initialised for the simulations. Although the estimated carbon inputs calculated based on the past land use were higher in Southwest Finland (Table 3), the initial SOC stocks were higher in Northern Savonia (Table 4, Fig. 3). This was mainly due to colder mean annual temperature in Northern Savonia (Table 1) that reduced the decomposition rates in the model in comparison to the decomposition rates in Southwest Finland. For both regions, the initial SOC stocks-as calculated 
Table 4 Steady-state SOC stocks $\left(\mathrm{SOC}_{\mathrm{t} 0}\right)$ and SOC stock changes $(\triangle \mathrm{SOC})$ for wheat production in the two case regions with different assumptions. T20 and T100 depict the length of the time horizon of the $\Delta$ SOC assessment, 20 and 100 years, respectively. I1 and I2 are the assumptions made on the land use history and the SOC stock status. I1 assumes the soil to be in a steady state with the mean regional agricultural land use (or crop distribution); I2 takes into account the LUC from forest to agriculture 120 years ago

Q1: $\triangle$ SOC due to ongoing wheat production

\begin{tabular}{|c|c|c|c|c|c|c|}
\hline & \multicolumn{3}{|c|}{ Southwest Finland } & \multicolumn{3}{|c|}{ Northern Savonia } \\
\hline & \multirow{3}{*}{$\begin{array}{l}\mathrm{SOC}_{\mathrm{t} 0} \\
\left(\mathrm{~kg} \mathrm{Cha}^{-1}\right)\end{array}$} & \multicolumn{2}{|c|}{$\Delta \mathrm{SOC}$} & \multirow{3}{*}{$\begin{array}{l}\mathrm{SOC}_{\mathrm{t} 0} \\
\left(\mathrm{~kg} \mathrm{Cha}^{-1}\right)\end{array}$} & \multirow{2}{*}{\multicolumn{2}{|c|}{$\frac{\Delta \text { SOC }}{\left(\mathrm{kg} \mathrm{Cha}^{-1} \mathrm{a}^{-1}\right)}$}} \\
\hline & & \multicolumn{2}{|c|}{$\left(\mathrm{kg} \mathrm{Cha}^{-1} \mathrm{a}^{-1}\right)$} & & & \\
\hline & & $\mathrm{T} 20$ & $\mathrm{~T} 100$ & & $\mathrm{~T} 20$ & $\mathrm{~T} 100$ \\
\hline I1 & 63,985 & 26 & 6 & 66,581 & -82 & -40 \\
\hline $\mathrm{I} 2$ & 82,517 & -31 & -33 & 91,007 & -160 & -91 \\
\hline \multicolumn{7}{|c|}{ Q2: $\triangle$ SOC due to change in management (adding cover crop) } \\
\hline & NR & 471 & 185 & NR & 422 & 172 \\
\hline
\end{tabular}

purely with inputs according to the average field use during the past 20 years (I1) —-were lower than those simulated considering a LUC from forest to agriculture 120 years ago (I2; Table 4, Fig. 3). This is a result of the high SOC stock of historical forests that still, after 120 years, affect the stocks due to the slow dynamics of SOC decomposition.

Simulated SOC stocks were decreasing in Northern Savonia (Fig. 3). In Southwest Finland, the stocks were increasing during the very first years, after which they increased or decreased depending on assumptions on the land use history and the year of simulation. This development was a result of the higher litter input in comparison to input used in the pre-run periods of I1 and $\mathrm{I} 2$ initialisations (Table 3), which still was not high enough to permanently compensate the continuously decomposing initial forest carbon stock of I2. The annual changes were larger in the beginning of the simulation periods but decreased over time. Therefore, the average SOC stock change estimates also depended on the length of the simulation period. The mean annual SOC change in Southwest Finland varied from -33 to $26 \mathrm{~kg} \mathrm{C} \mathrm{ha}^{-1} \mathrm{a}^{-1}$ depending on the assumptions on the land use history and simulation period (Table 4, Fig. 4). For Northern Savonia, the range was from -160 to $-40 \mathrm{~kg} \mathrm{C} \mathrm{ha}^{-1} \mathrm{a}^{-1}$.

\subsubsection{Q2: SOC change due to land management change}

The introduction of clover cover crop increased SOC stocks in both regions (Table 4, Fig. 5). As in Q1, the annual changes were larger in the beginning of the simulation periods but decreased over time. The SOC stock changes due to the introduction of clover cover crop in Southwest Finland were 471 or $185 \mathrm{~kg} \mathrm{C} \mathrm{ha}^{-1}$ $\mathrm{a}^{-1}$ for the simulation periods of 20 and 100 years, respectively. For Northern Savonia, the SOC stock changes due to cover crop were accordingly 422 and $172 \mathrm{~kg} \mathrm{C} \mathrm{ha}^{-1} \mathrm{a}^{-1}$.

\subsection{The net global warming impacts}

\subsubsection{Q1: overall global warming impacts of wheat production}

The majority of the global warming impact of wheat production is caused by the production of input materials (such as fertilisers, limestone, seeds) and fuel (0.24 and $0.29 \mathrm{~kg}$ $\mathrm{CO}_{2}$-eq/kg in Southwest Finland and Northern Savonia, respectively) and $\mathrm{N}_{2} \mathrm{O}$ emissions from fertiliser use and decomposition of crop residues $\left(0.24\right.$ and $0.28 \mathrm{~kg} \mathrm{CO}_{2}$-eq/
Fig. 3 SOC stock dynamics due to the wheat production in the two study regions. I1 assumes the soil to be in a steady state with the carbon input of mean regional agricultural crop production; I2 takes into account the LUC from forest to agriculture 120 years ago

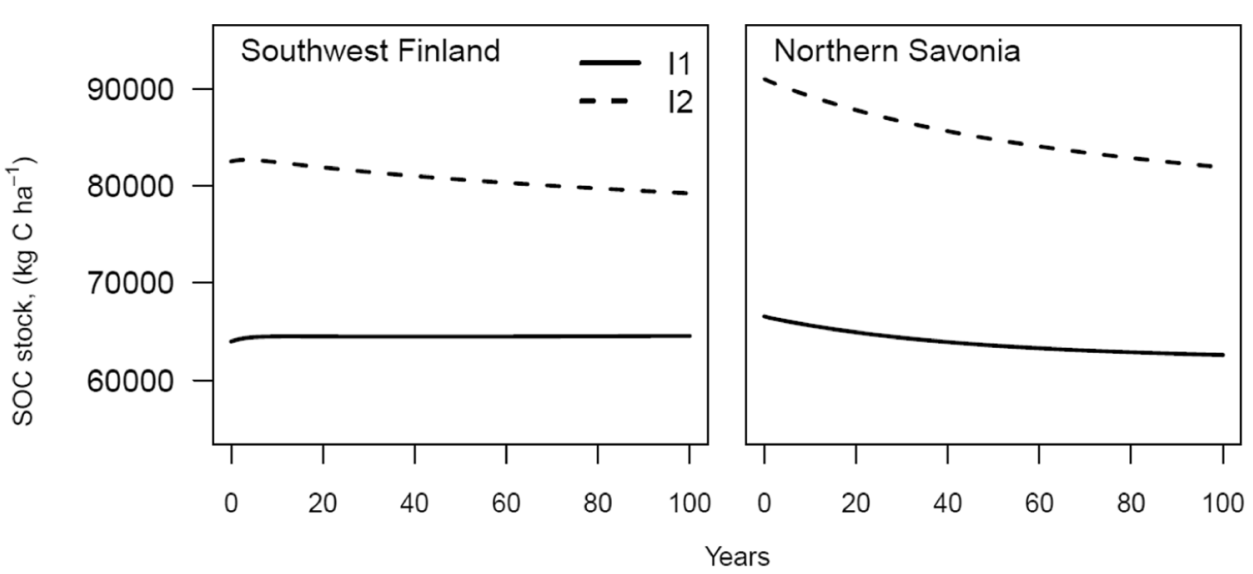


Fig. 4 Mean annual SOC stock changes $(\triangle \mathrm{SOC})$ due to the wheat production calculated over time periods from 1 to 100 years for the two study regions. I1 assumes the soil to be in a steady state with the mean regional agricultural land use (or crop distribution); I2 takes into account the LUC from forest to agriculture 120 years ago

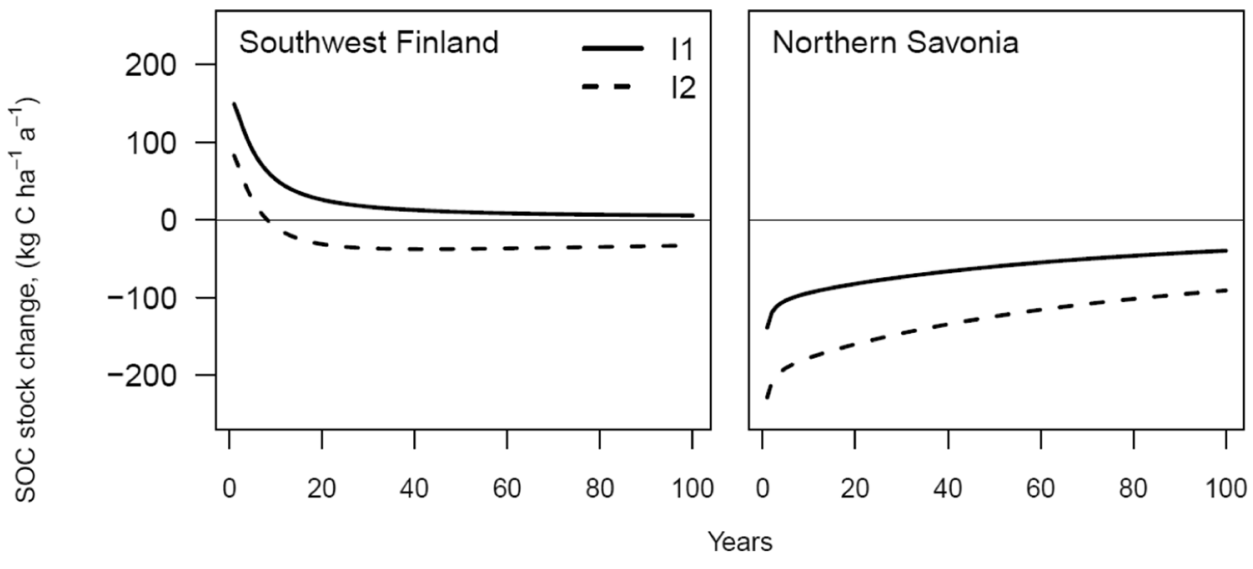

$\mathrm{kg}$ in Southwest Finland and Northern Savonia, respectively). The global warming impact of wheat production without accounting for SOC changes was 0.58 and $0.68 \mathrm{~kg} \mathrm{CO} 2$-eq/ $\mathrm{kg}$ in Southwest Finland and Northern Savonia, respectively. The overall impact of SOC stock changes for the global warming impacts of wheat production was low. When the SOC stock changes (Table 4) were included in the calculation, $4 \%$ and $1 \%$ of the total GHG emissions were removed for the time frames 20 and 100 years, respectively, when the initialisation of SOC stocks was done by assuming the soil to be in a steady state with the mean regional agricultural land use (Fig. 6a) in Southwest Finland. For Northern Savonia, the impact was $14 \%$ and $7 \%$ for the same time frames (Fig. 6b). When the LUC from forest to agriculture 120 years ago was included in the assessment, the SOC changes increased the overall global warming impact by $5 \%$ for Southwest Finland for both time frames and by $27 \%$ and $16 \%$ for Northern Savonia for the time frames 20 and 100 years, respectively.

\subsubsection{Q2: net global warming impacts due to change in land management}

Adding cover crop into the cultivation system of wheat increased the global warming impact by $0.08 \mathrm{~kg} \mathrm{CO}_{2}$-eq/ $\mathrm{kg}$ due to $\mathrm{N}_{2} \mathrm{O}$ emissions from the decomposition of crop residues. Thus, the overall global warming impacts of wheat production with cover crops without accounting for SOC changes were 0.66 and $0.77 \mathrm{~kg} \mathrm{CO}_{2}$-eq/ $\mathrm{kg}$ yield in Southwest Finland and Northern Savonia, respectively. Including the SOC stock changes (Table 4) in the calculation removed $67 \%$ and $26 \%$ of the total GHG emissions for the time frames 20 and 100 years, respectively, (Fig. 7a) in Southwest Finland. For Northern Savonia, the removal was $64 \%$ and $26 \%$ for the same time frames (Fig. 7b).

\section{Discussion}

The results of the study supported the hypothesis concerning the important role of decisions and assumptions within the SOC modelling process in uncertainties related to estimated SOC stocks. The case simulations for northern wheat production systems in this study showed that soils in the study regions could be either source or sink of $\mathrm{C}$ depending on modelling assumptions (Table 4). Both the assumptions made on land use history as well as time horizon covered by the analysis had considerable impacts on the model results. Uncertainties brought by these uncertainties can, depending
Fig. 5 Mean annual SOC stock change $(\triangle \mathrm{SOC})$ due to land management change, i.e. cover crop. The vertical dashed lines mark the two simulation period time frames: 20 and 100 years

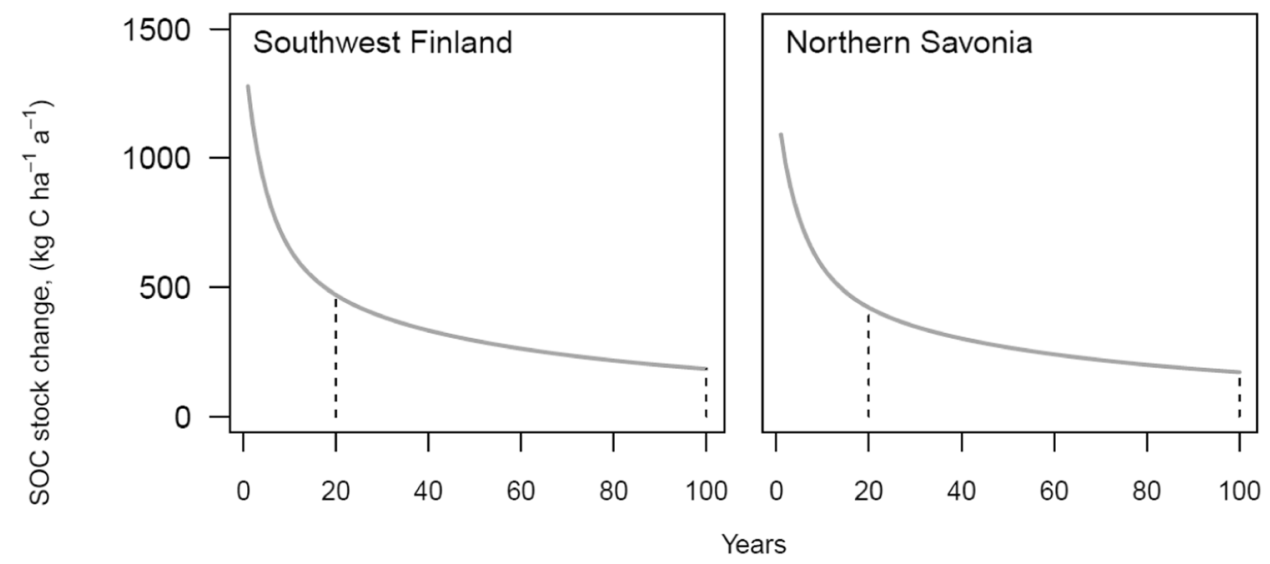


a)

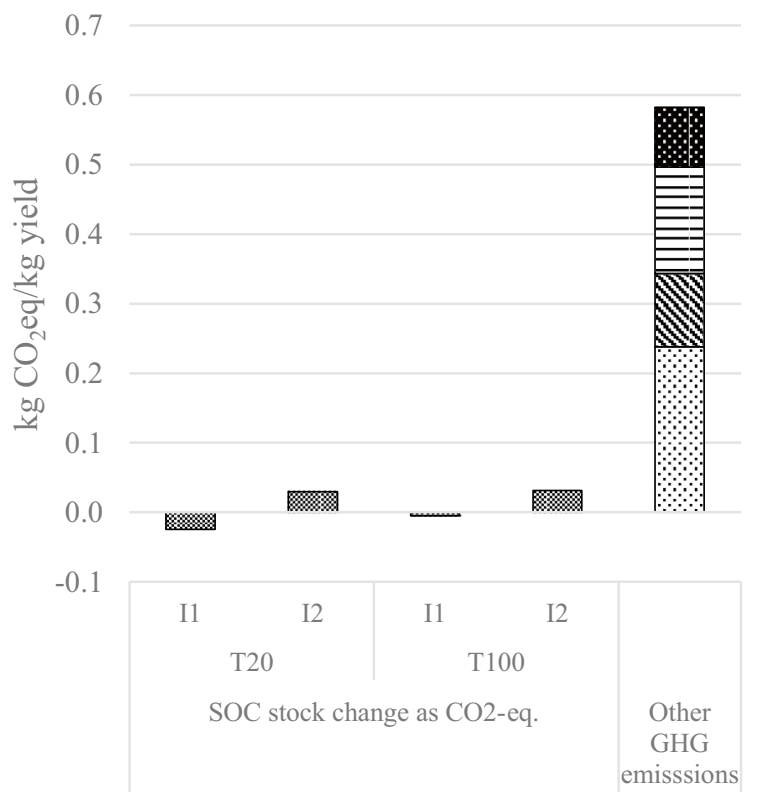

Fig. 6 Total annual global warming impact of production of $1 \mathrm{~kg}$ of spring wheat in Southwest Finland a) and Northern Savonia b). I1 represents emissions from soil $\mathrm{C}$ stock change calculated based

on the situation, be larger than those reported due to uncertainties in soil model input estimates (Riggers et al. 2019), soil model calibrations (Shi et al. 2018), or over different soil models (Riggers et al. 2019). The sensitivity analysis for

a)

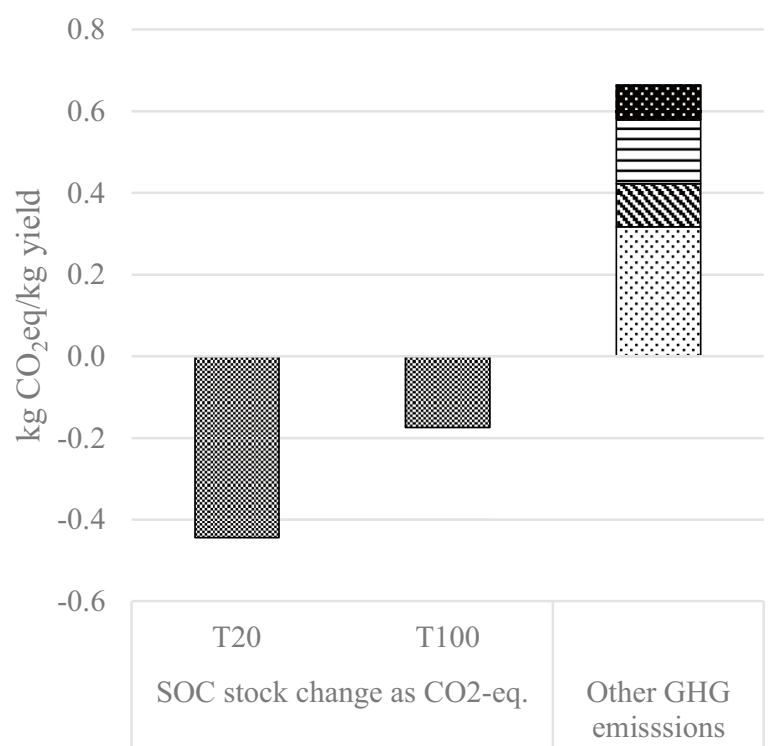

Fig. 7 The total global warming impact of of production of $1 \mathrm{~kg}$ of spring wheat with the clover cover crop including $\mathrm{CO} 2$ emissions from SOC change (mineral soils) in Southwest Finland a) and North- b)

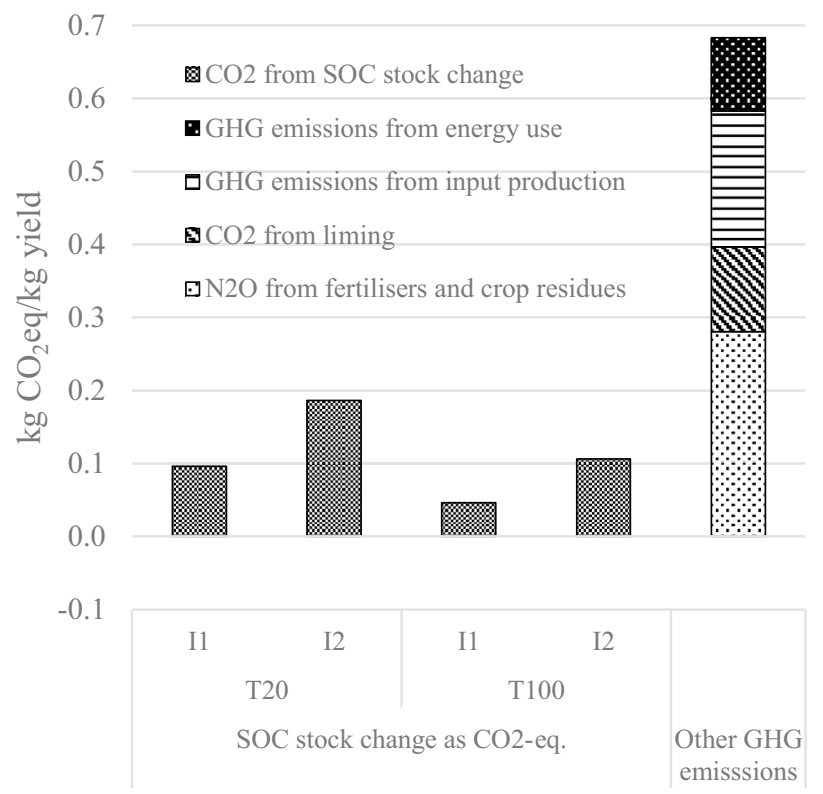

on recent land use and $\mathrm{I} 2$ based on historical land use. T20 represents calculations based on time frame over 20 years and T100 over 100 years

the litter inputs (see Supplementary material) showed that both the SOC stocks and stock changes were sensitive to the litter inputs applied (Fig S1) but that the systematic errors brought by decisions within the modelling process were at

b)

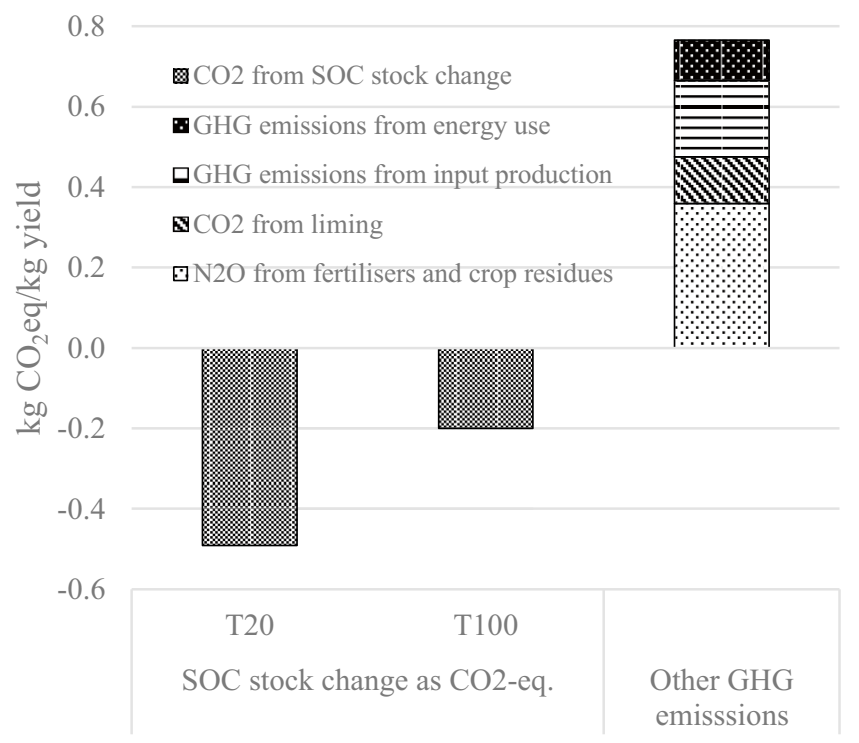

ern Savonia b) for Q2. T20 represents calculations based on a time frame over 20 years and T100 over 100 years 
least equally important sources of uncertainty. In a Yasso07 evaluation study, Karhu et al. (2012) showed the uncertainties due to both litter input and model parameters created a relatively moderate range of uncertainty when simulating the carbon stocks of agricultural soils with organic amendments. Peltoniemi et al. (2006) found in a sensitivity analysis made with the Yasso model (predecessor of Yasso07) for the forest soil carbon stocks and stock changes that the initial state clearly dominated the SOC stock change estimates. The same holds for the agricultural soils (Akujärvi et al. 2014). In the present study, the differences in the assumptions caused an overall variation that corresponded more than $60 \%$ of the other direct and indirect GHG emissions from wheat production (Figs. 6 and 7). This underlines the importance of considering the impacts of different assumptions for the LCA results and interpretation of the results.

\subsection{Comparison to previous studies}

The magnitude of the SOC change estimates due to wheat production (Table 4) suit the ranges reported in previous Finnish studies. Palosuo et al. (2016) in their analysis done with the Yasso07 model reported average regional SOC changes in cropland soils to range during 1990-2013 from a decrease of $60 \mathrm{~kg} \mathrm{C} \mathrm{ha}^{-1}$ year $^{-1}$ to an increase of $30 \mathrm{~kg}$ $\mathrm{C} \mathrm{ha}^{-1}$ year $^{-1}$ with high interannual variability. These figures are somewhat smaller than those reported using Finnish national soil monitoring (Heikkinen et al. 2013), where SOC stocks in Finnish cultivated soils have decreased by ca. $220 \mathrm{~kg} \mathrm{C} \mathrm{ha}^{-1}$ year $^{-1}$ over the period 1974-2009. The SOC changes for cereals analysed by Saarinen et al. (2019) for the period from 1998 to 2009 showed decreases of ca. $110-140 \mathrm{~kg} \mathrm{C}^{-1}$ year $^{-1}$ based on the same soil inventory data. The SOC changes for cereals in their results were at the same level as for oilseeds ( $120 \mathrm{~kg} \mathrm{C}$ decrease $\mathrm{ha}^{-1} \mathrm{year}^{-1}$ ) but greater than for grass leys ( $30 \mathrm{~kg} \mathrm{C}$ increase ha ${ }^{-1}$ year $\left.^{-1}\right)$. This can be explained by greater carbon input levels from plant litter in grass leys.

The change in soil management caused a SOC stock increase of up to $471 \mathrm{~kg} \mathrm{C} \mathrm{ha}^{-1}$ year $^{-1}$ in this study (Table 4, Q2), which corresponds to $67 \%$ of the life cycle global warming impacts of wheat production (Table 7). Additionally, in previous international studies combining the SOC changes in LCAs, changes in soil management have caused great SOC sequestration (Petersen et al. 2013; van Middelaar et al. 2016; Stanley et al. 2018; Bessou et al. 2020). The values cannot, however, be directly compared, because of the cropping systems, assessment methods, and assumptions differed between the studies.

When no particular management change was studied (Q1), the impact of SOC changes on the overall global warming impact was relatively small (Fig. 6). Similar results were presented by Knudsen et al. (2019), who found that including soil carbon changes removed 5-18\% of the global warming potential of European milk production. In a study of Swedish pasta production, Röös et al. (2011) reported a decrease of ca. $14 \%$ of the global warming impact when including the SOC changes in the calculation. Also, in a study of Norwegian cereal production, including the SOC changes increased the global warming impact by ca. $11 \%$ according to Korsaeth et al. (2014). For Australia, however, Sevenster et al. (2019) found that the estimated SOC changes corresponded to a change varying from a decrease of $56 \%$ to an increase of $54 \%$ of the global warming impact of Australian's wheat production. In their study, Sevenster et al. took into account the impacts of whole crop rotations, which had a great impact on the results. The results of these studies cannot, however, be directly compared, because different methods and assumptions were used in each of them to assess the SOC changes.

Compared with previous studies assessing the global warming impact of wheat production in other countries, the results of the present study (without accounting for SOC changes, 0.58 and $0.68 \mathrm{~kg} \mathrm{CO}_{2}$-eq/kg in Southwest Finland and Northern Savonia, respectively) are relatively high. Similar results $\left(0.5-0.7 \mathrm{~kg} \mathrm{CO}_{2}\right.$-eq $\left./ \mathrm{kg}\right)$ have been previously reported by Korsaeth et al. (2014) for wheat in Norway. However, in previous studies, also smaller values have been reported for example in Denmark $\left(0.43 \mathrm{~kg} \mathrm{CO}_{2}\right.$-eq/ $\mathrm{kg}$ wheat $\mathrm{DM}$, equivalent to $0.37 \mathrm{~kg} \mathrm{CO}_{2}$-eq $/ \mathrm{kg}$ wheat in harvesting dry matter content, $86 \%^{1}$ ) (Mogensen et al. 2014), Italy (0.27-0.43 $\mathrm{kg} \mathrm{CO}_{2}$-eq/kg wheat) (Goglio et al. 2012), the USA ( 0.45 and $0.49 \mathrm{~kg} \mathrm{CO}_{2}$-eq $/ \mathrm{kg}$ organic and conventional wheat, respectively) (Meisterling et al. 2009) and Australia (0.27-0.38 kg CO 2 -eq/kg wheat) (Sevenster et al. 2019), considering the global warming impact without SOC changes. The difference can be caused by, for example, different yield levels. In the present study, the yield levels were relatively low 3650 and $3210 \mathrm{~kg} / \mathrm{ha}$ in Southwest Finland and Northern Savonia, respectively) compared with, for example, Denmark (7400 kg/ha) (Mogensen et al. 2014) and Italy (5800-9300 kg/ha). In the USA, however, the yield levels were only 2100 and $2800 \mathrm{~kg} / \mathrm{ha}$ for organic and conventional wheat, respectively. On the other hand, the nitrogen fertilization level in the USA was lower as well, $66 \mathrm{~kg} / \mathrm{ha}$.

There were also differences in lime use between countries. For example, the studies related to wheat production in Italy (Goglio et al. 2012) and the USA (Meisterling et al. 2009) reported that lime was not used in the studied production systems. In the present study liming caused a global warming impact of ca. $0.1 \mathrm{~kg} \mathrm{CO}$-eq/kg wheat, which corresponds to 17 or $18 \%$ of the total global warming impact of wheat production in Southwest Finland and Northern

\footnotetext{
${ }^{1}$ Palosuo et al. (2016)
} 
Savonia, respectively (without accounting for SOC changes). The assumptions on lime use in the present study are based on national liming recommendations, and part of the farms may in reality use smaller amounts of lime than what was assumed here. If, for example, the actual lime use would be $50 \%$ of the amount assumed in the present study, the global warming impact of wheat production would be 8-9\% smaller, 0.48, and $0.57 \mathrm{~kg} \mathrm{CO}_{2}$-eq/kg wheat in Southwest Finland and Northern Savonia, respectively.

\subsection{Soil model initialisation}

Initial SOC pools of soil models are key parameters determining the trajectories of SOC development during the simulations (Foereid et al. 2012). In the case of this study, depending on the initialisation method, the studied soils under wheat cultivation in South-West Finland could even be either a source or a sink of carbon. Unfortunately, there is no straightforward answer to how the initialisation should be done. Steady-state assumption, spin-off runs, empirical observations, and their combinations are in use for different models (Peltoniemi et al. 2007; Riggers et al. 2019). The assumption that soil is in a steady state with respect to current or very recent inputs (I1) is most likely too simple as it overlooks the long-term dynamics of the SOC stocks and may therefore lead to an underestimation of the stocks. For considering the past land use and its impacts, detailed information about the land use history of the targeted area would be essential and that information is rarely available. However, using spin-up periods of a couple of decades already have been noticed to effectively reduce the uncertainties of SOC estimates due to soil model initialisation (Peltoniemi et al. 2006).

The impact of model initialisation also underlines the importance of the assessment unit. Given that cropping history, climate and soil conditions affect the crop production and SOC dynamics, it is important that the area considered has a relatively uniform land use history, soil and climatic conditions and field use practices. For example, Sevenster et al. (2019), who assessed the long-term soil carbon changes of Australian agricultural products, modelled the changes for each Australian Agro-Ecological Region under current management practices based on their typical crop rotations. The results of this Finnish study showed that differences in land use history between the two Finnish regions also created differences to their estimated development of SOC stocks.

Overall, the steady-state assumption (I1) may seem more motivating for the actors of the production chain to remove GHG emissions with particular mitigation measures as historical land use has less impact on the assessment. Of course, this applies in countries like Finland where the initial
SOC stock is large (Heikkinen et al. 2013). The opposite situation might be the case in countries which have a long cultivation history and the SOC stock has decreased previously. Instead, considering historical land use might give more realistic impacts of mitigation actions, but it puts the farmers in different positions depending on the land use history of their fields.

\subsection{Time horizon of the assessment}

In the LCA, the emissions or impacts considered are normally those created within the analysed time frame. However, due to long-term dynamics of SOC decomposition, a longer time frame needs to be accounted for when considering the management impacts on SOC stocks (Reap et al. 2008; Levasseur et al. 2010). According to Goglio et al. (2015), the time horizon of LCAs that consider C dynamics should be at least 20 years, but a horizon of up to 100 years would be preferable, especially in cooler climates where the decomposition of organic matter is slower. Petersen et al. (2013), who tested three time perspectives, 20, 100 and 200 years, for a bioenergy system in Denmark and soybean production systems in China, concluded that the SOC changes should be estimated with the same time frame (100 years) as the rest of the total global warming impact in the LCA study.

The results of this Finnish study (Fig. 4) showed larger SOC changes when the time period of assessment was 20 years in comparison to 100 years, which is in line with the results of Petersen el al. (2013) and van Middelaar et al. (2016). Both choices, short and long assessment periods, can be justified depending on the initial aim of the study. If the aim is to cover the overall long-term impacts of activity, then the assessment period should be long enough to reach a new equilibrium (steady-state) in the SOC stock. This, however, may take even thousands of years, depending on the model parameters describing the slowest decomposition processes in the soil. On the other hand, if focusing on the acute need to store more carbon in soils to slow down global warming (Griscom et al. 2017), then choosing a shorter timeline could also be justified with the goal to identify possible ways to enhance SOC sequestration in the short term. The time frame should therefore be a deliberate choice of the planning phase of the LCA study, which should be transparently reported together with respective results.

In the present study, the impact of climate change on carbon decomposition in the soil was not considered, but rather static, mean weather data was used. This choice was made because the intention was to only show the impact of crop production. This is also in line with using a mean estimate for crop yield and input use in the assessment of the overall GHG emissions caused by wheat production. However, considering the future trends in SOC stocks, covering also 
the impacts of changing climate conditions is possible with model-based assessments (Sevenster et al. 2019). For consistency, the impact of climate change should then also be taken into account in estimating future yields and the use of fertilisers and other inputs, which would account for the use of dynamic crop-climate-soil models that also cover impacts of changes in environment and management on crop growth.

\subsection{Other assumptions}

In addition to the SOC changes, some studies have also considered the net effect of timing of emissions and the decay of $\mathrm{CO}_{2}$ released in the atmosphere due to absorption in sinks (primarily the oceans) (Brandão et al. 2019). For example, Petersen et al. (2013) used the Bern Carbon Cycle Model to include this decay pattern. In this study, however, we focused on the changes occurring in the soil and the impacts of different assumptions and decisions related to land use history and the time frame of the analysis from the point of view of the quantified soil stocks and the $\mathrm{CO}_{2}$ dynamics in the atmosphere were not considered. This simplification has impacts on the comparison of SOC stock changes to the other GHG emissions of the production system. We assumed that the climate impact of negative $\mathrm{CO}_{2}$ emissions can be considered equal to the equivalent GHG emissions. This assumption has recently been challenged by Zickfeld et al. (2021), who reported that that an emission of $\mathrm{CO}_{2}$ into the atmosphere is more effective at raising atmospheric $\mathrm{CO}_{2}$ than a $\mathrm{CO}_{2}$ removal is at lowering atmospheric $\mathrm{CO}_{2}$. These assumptions, additional to the assumptions involved in the SOC modelling, should be discussed in more detail in future studies to provide a more complete view of the carbon cycles.

A traditional question in the assessment of SOC changes in LCA is the choice of the reference state for SOC, i.e. the SOC stock that the simulated results are compared to (Milà i Canals et al. 2007; Koellner et al. 2013). For bioenergy systems, UNEP-SETAC (Koellner et al. 2013) and Soimakallio et al. (2015) have recommended a biome-dependent natural state as a reference system. For bioenergy production systems, this kind of a choice is reasonable as the biomass can come from a variety of sources, such as forestry, agriculture or waste management. Koponen et al. (2018) suggested that if the effects of bioenergy are studied as part of total human activity, they should be compared with a reference system without any human activities. If, on the other hand, the goal is to study the effect of a change in bioenergy use, the reference system should describe the most likely alternative land use. This compares to the approach taken for Q2. Accordingly, Petersen et al. (2013), van Middelaar et al. (2016), and Stanley et al. (2018) have studied the impacts of certain management changes on the SOC stocks by comparing the prevailing land management to an improved management.

For agricultural systems, the reference land uses have varied. Knudsen et al. (2019) selected wheat as the reference crop in their study focusing on the SOC changes caused by feed crop production in Europe, because wheat is a common crop in the European landscape and was therefore considered to largely determine the equilibrium of SOC stocks. In Denmark, wheat production without manure input and with no straw removed has been shown to have a $\mathrm{C}$ sequestration close to $0 \mathrm{~g} \mathrm{C} / \mathrm{ha} /$ year in the long term (Heidmann et al. 2001). In many other parts of the world (including more Northern parts of Europe), however, wheat is not a prevailing crop in all agricultural regions, and a more reasonable choice of reference land use situation is the regional average field use, which represents alternative crops that are possible and most likely to be produced in the same area. This is the approach taken for Q1 in this study.

In the present study, wheat monoculture was considered a simplified example cropping system to demonstrate the impacts of the key assumptions. A similar assumption has also been made in most of the previous LCA studies, taking into account that SOC changes have only considered single crops (Petersen et al. 2013; van Middelaar et al. 2016; Stanley et al. 2018; Knudsen et al. 2019). However, in a real-life situation, different crops with different $\mathrm{C}$ inputs alternate in the same field parcel from year to year in crop rotation. Sevenster et al. (2019) studied crop rotations attributing the mean annual SOC change equally to each crop. Their results showed that the applied crop rotation (including different crops with different carbon inputs) can have a great impact on the total global warming impact of wheat production, which is also reflected in the results for Q2 that added cover crop to the wheat cropping system. In this study, the questions addressed on model initialisation and simulation periods are also valid for cropping system assessments. Additionally, defining the impacts of individual crops with the approach used in this study can be used to identify crops with a higher potential for SOC sequestration and thus help to design more sustainable crop rotations in the future.

From the point of view of system boundaries, one decision to be made in the SOC change assessments is the depth of the soil profile considered. Petersen (2013) recommends to analyse a soil depth of $0-100 \mathrm{~cm}$ in order to capture a more precise estimate of the soil $\mathrm{C}$ changes in the root zone of most crop plants. In the present study, the soil model Yasso07 applied covered a soil layer to a depth of one meter. For many other models, the soil layer covered is shallower concentrating on the typical ploughing depths. The IPCC tier 1 approach to estimate changes in soil C stocks (Eggleston et al. 2006) only includes a soil layer of $0-30 \mathrm{~cm}$. The depth covered should be checked, for example, when comparing 
the SOC change estimates provided in different studies. A deep enough layer is also important as management may affect differently the SOC of soil layers at different depths. For example, Ogle et al. (2019) found the SOC change at different soil depths to vary depending on climate and soil characteristics. For most models, it would, however, be challenging to reproduce such a result as in many of them the whole soil layer covered is assumed homogeneous.

\section{Conclusions and recommendations}

From the results obtained, it is concluded that there are important implicit and explicit decisions in the SOC stock modelling process that remarkably affect the results and create uncertainty in them. In the case of this study, the assumptions even turned the soil to be either a source or sink of C. The model used in this study was Yasso07, but the best SOC model to apply depends on the land use type and availability of locally calibrated and evaluated models. Also, the use of model ensembles is getting increasingly common also in the field of SOC assessments (Farina et al. 2021). Although there are differences among the SOC dynamics described by different models, decisions such as those focused on in this study have high impact and are needed regardless of the SOC model applied. To ensure the comparability of any modelling results, it is therefore essential that all the decisions made in the modelling process are transparently reported and communicated. Regarding the model initialisation and time horizon of the assessment period, no definite rules can be set on the preferable assumptions that should be used in all circumstances. The choice of assumptions should be made based on the scope and goal definition of the LCA study, and they are also affected by the data availability.

When the interest is in detecting the impact of a certain change in management on SOC stock, the prevailing management should be used as the reference situation in the SOC modelling. However, if more general impacts of crop production are of interest, it is suggested that the reference is chosen in a way that would reflect the current agricultural land use situation in the region, e.g. the regional average field use, which represents alternative crops that are possible and most likely to be produced in the same area.

To take into account long-term impacts, it is recommended that the SOC changes are estimated with a time frame of at least 100 years. However, if the goal of the study is to identify possible ways to enhance SOC sequestration in the short term to acutely slow down global warming, then choosing a shorter timeframe could also be justified with the goal of the study.

Supplementary information The online version contains supplementary material available at https://doi.org/10.1007/s11367-021-01967-1.
Acknowledgements This work has been carried out in the SusBioEcon (Sustainable bioeconomy: holistic multi-criteria assessment framework) project funded by the Natural Resources Institute Finland (Luke). Additional support has also been received from the CARBO (Effect of cultivation techniques on the carbon sequestration potential of grass) project funded by Business Finland.

Funding Open access funding provided by Natural Resources Institute Finland (LUKE).

Open Access This article is licensed under a Creative Commons Attribution 4.0 International License, which permits use, sharing, adaptation, distribution and reproduction in any medium or format, as long as you give appropriate credit to the original author(s) and the source, provide a link to the Creative Commons licence, and indicate if changes were made. The images or other third party material in this article are included in the article's Creative Commons licence, unless indicated otherwise in a credit line to the material. If material is not included in the article's Creative Commons licence and your intended use is not permitted by statutory regulation or exceeds the permitted use, you will need to obtain permission directly from the copyright holder. To view a copy of this licence, visit http://creativecommons.org/licenses/by/4.0/.

\section{References}

Akujärvi A, Heikkinen J, Palosuo T, Liski J (2014) Carbon budget of Finnish croplands - Effects of land use change from natural forest to cropland. Geoderma Reg 2-3:1-8. https://doi.org/10. 1016/j.geodrs.2014.09.003

Bessou C, Tailleur A, Godard C et al (2020) Accounting for soil organic carbon role in land use contribution to climate change in agricultural LCA: which methods? Which impacts? Int J Life Cycle Assess 25:1217-1230. https://doi.org/10.1007/ s11367-019-01713-8

Bolinder MA, Janzen HH, Gregorich EG et al (2007) An approach for estimating net primary productivity and annual carbon inputs to soil for common agricultural crops in Canada. Agric Ecosyst Environ 118:29-42. https://doi.org/10.1016/j.agee. 2006.05.013

Brandão M, Kirschbaum MUF, Cowie AL, Hjuler SV (2019) Quantifying the climate change effects of bioenergy systems: Comparison of 15 impact assessment methods. GCB Bioenergy 11:727-743. https://doi.org/10.1111/gcbb.12593

Clune S, Crossin E, Verghese K (2017) Systematic review of greenhouse gas emissions for different fresh food categories. J Clean Prod 140:766-783. https://doi.org/10.1016/j.jclepro.2016.04.082

Cowie AL, Kirschbaum MUF, Ward M (2007) Options for including all lands in a future greenhouse gas accounting framework. Environ Sci Policy 10:306-321. https://doi.org/10.1016/j. envsci.2007.03.003

Eggleston HS, Intergovernmental Panel on Climate Change, National Greenhouse Gas Inventories Programme, Chikyū Kankyō Senryaku Kenkyū Kikan (2006) 2006 IPCC guidelines for national greenhouse gas inventories

European Commission, Joint Research Centre (2010) General guide for Life Cycle Assessment: provisions and action steps. Publications Office, Luxembourg

Farina R, Sándor R, Abdalla M et al (2021) Ensemble modelling, uncertainty and robust predictions of organic carbon in long-term bare-fallow soils. Glob Change Biol 27:904-928. https://doi.org/ $10.1111 / \mathrm{gcb} .15441$ 
Foereid B, Bellamy PH, Holden A, Kirk GJD (2012) On the initialization of soil carbon models and its effects on model predictions for England and Wales. Eur J Soil Sci 63:32-41. https://doi.org/10. 1111/j.1365-2389.2011.01407.x

Forster P, Ramaswamy V, Artaxo P, Berntsen T, Betts R, Fahey DW, Haywood J, Lean J, Lowe DC, Myhre G, Nganga J, Prinn R, Raga G, Schulz M, Van Dorland R (2007) Changes in Atmospheric Constituents and in Radiative Forcing. In: Climate Change 2007: The Physical Science Basis. Contribution of Working Group I to the Fourth Assessment Report of the Intergovernmental Panel on Climate Change. Cambridge University Press, Cambridge, United Kingdom and New York, NY, USA

Goglio P, Bonari E, Mazzoncini M (2012) LCA of cropping systems with different external input levels for energetic purposes. Biomass Bioenergy 42:33-42. https://doi.org/10.1016/j.biombioe. 2012.03.021

Goglio P, Smith WN, Grant BB et al (2015) Accounting for soil carbon changes in agricultural life cycle assessment (LCA): a review. J Clean Prod 104:23-39. https://doi.org/10.1016/j.jclepro.2015. 05.040

Griscom BW, Adams J, Ellis PW et al (2017) Natural climate solutions. Proc Natl Acad Sci 114:11645-11650. https://doi.org/10.1073/ pnas. 1710465114

Grönroos J, Voutilainen P (2001) Maatalouden tuotantotavat ja ympäristö. Inventaarioanalyysin tulokset (Agricultural production methods and the environment. Results of inventory analysis). Suomen ympäristökeskuksen moniste 231

Guinée JB, Heijungs R (2005) Life Cycle Assessment. In: Kirk-Othmer Encyclopedia of Chemical Technology. American Cancer Society

Heidmann T, Nielsen J, Olesen SE et al (2001) Changes in the Amount of Carbon (C) and Nitrogen (N) Content of Soil: Samplesfrom a Square Grid in Denmark 1987-1998. Plant Sci No 54

Heikkinen J, Keskinen R, Regina K et al (2020) Estimation of carbon stocks in boreal cropland soils - methodological considerations. Eur J Soil Sci. https://doi.org/10.1111/ejss.13033

Heikkinen J, Ketoja E, Nuutinen V, Regina K (2013) Declining trend of carbon in Finnish cropland soils in 1974-2009. Glob Change Biol 19:1456-1469. https://doi.org/10.1111/gcb.12137

ISO 14040 (2006) Environmental management — Life cycle assessment - Principles and framework

ISO 14044 (2006) Environmental management — Life cycle assessment - Requirements and guidelines

ISO 14067 (2018) Greenhouse gases — Carbon footprint of products - Requirements and guidelines for quantification

Känkänen H, Eriksson C, Räkköläinen M, Vuorinen M (2003) Soil nitrate $\mathrm{N}$ as influenced by annually undersown cover crops in spring cereals. Agric Food Sci Finl 2003:165-176

Karhu K, Gärdenäs AI, Heikkinen J et al (2012) Impacts of organic amendments on carbon stocks of an agricultural soil Comparison of model-simulations to measurements. Geoderma 189-190:606-616. https://doi.org/10.1016/j.geoderma.2012.06. 007

Knudsen MT, Dorca-Preda T, Djomo SN et al (2019) The importance of including soil carbon changes, ecotoxicity and biodiversity impacts in environmental life cycle assessments of organic and conventional milk in Western Europe. J Clean Prod 215:433-443. https://doi.org/10.1016/j.jclepro.2018.12.273

Koellner T, de Baan L, Beck T et al (2013) UNEP-SETAC guideline on global land use impact assessment on biodiversity and ecosystem services in LCA. Int J Life Cycle Assess 18:1188-1202. https://doi. org/10.1007/s11367-013-0579-z

Koponen K, Soimakallio S, Kline KL et al (2018) Quantifying the climate effects of bioenergy - Choice of reference system. Renew Sustain Energy Rev 81:2271-2280. https://doi.org/10.1016/j.rser. 2017.05.292
Korsaeth A, Henriksen TM, Roer A-G, Hammer Strømman A (2014) Effects of regional variation in climate and SOC decay on global warming potential and eutrophication attributable to cereal production in Norway. Agric Syst 127:9-18. https://doi.org/10.1016/j. agsy.2013.12.007

Lal R (2004) Soil Carbon Sequestration Impacts on Global Climate Change and Food Security. Science 304:1623-1627. https://doi. org/10.1126/science.1097396

Levasseur A, Lesage P, Margni M et al (2010) Considering Time in LCA: Dynamic LCA and Its Application to Global Warming Impact Assessments. Environ Sci Technol 44:3169-3174. https:// doi.org/10.1021/es9030003

Luke (2016) Farm structure statistics. Basic tillage of agricultural area by production sector $2015-16$

Luke Statistics (2020a) Crop production statistics. Yield of the main crops. Natural Resources Institute Finland. http://statdb.luke. fi/PXWeb/pxweb/en/LUKE/LUKE__02\%20Maatalous_04\% 20Tuotanto__14\%20Satotilasto/?tablelist $=$ true \&rxid=dc711a9ede6d-454b-82c2-74ff79a3a5e0

Luke Statistics (2020b) Taloustohtori. Pintamaa maakunnittain 2011 (Topsoil by region). Natural Resources Institute Finland. https://portal. mtt.fi/portal/page/portal/taloustohtori/maannostieto/vakioraportit/ pintamaalajit_kansallinen_luokitus/pintamaa_maakunnittain

Luke Statistics (2020c) Number of Livestock. Natural Resources Institute Finland. https://stat.luke.fi/en/number-of-livestock

Meisterling K, Samaras C, Schweizer V (2009) Decisions to reduce greenhouse gases from agriculture and product transport: LCA case study of organic and conventional wheat. J Clean Prod 17:222-230. https://doi.org/10.1016/j.jclepro.2008.04.009

Mikkola HJ, Ahokas J (2009) Energy ratios in Finnish agricultural production. Agric Food Sci 2009:332-346

Milà i Canals L, Romanyà J, Cowell SJ, (2007) Method for assessing impacts on life support functions (LSF) related to the use of 'fertile land' in Life Cycle Assessment (LCA). J Clean Prod 15:1426-1440. https://doi.org/10.1016/j.jclepro.2006.05.005

Minasny B, Malone BP, McBratney AB et al (2017) Soil carbon 4 per mille. Geoderma 292:59-86. https://doi.org/10.1016/j.geoderma. 2017.01.002

Moberg E, Walker Andersson M, Säll S et al (2019) Determining the climate impact of food for use in a climate tax-design of a consistent and transparent model. Int J Life Cycle Assess 24:17151728. https://doi.org/10.1007/s11367-019-01597-8

Mogensen L, Kristensen T, Nguyen TLT et al (2014) Method for calculating carbon footprint of cattle feeds - including contribution from soil carbon changes and use of cattle manure. J Clean Prod 73:40-51. https://doi.org/10.1016/j.jclepro.2014.02.023

Nijdam D, Rood T, Westhoek H (2012) The price of protein: Review of land use and carbon footprints from life cycle assessments of animal food products and their substitutes. Food Policy 37:760-770. https://doi.org/10.1016/j.foodpol.2012.08.002

Nordkalk (2006) Ympäristöraportti (Environmental report). https:// www.nordkalk.fi/document/1/353/258f594/Ymparistoraportti 2006.pdf

Nordkalk (2019) Kalkitusopas (Liming guide). https://www.nordkalk. fi/document/1/788/831b55b/Nordkalk_Kalkitusopas.pdf

Ogle SM, Alsaker C, Baldock J et al (2019) Climate and Soil Characteristics Determine Where No-Till Management Can Store Carbon in Soils and Mitigate Greenhouse Gas Emissions. Sci Rep 9:1-8. https://doi.org/10.1038/s41598-019-47861-7

Pachauri RK, Allen MR, Barros VR et al (2014) Climate Change 2014: Synthesis Report. Contribution of Working Groups I, II and III to the Fifth Assessment Report of the Intergovernmental Panel on Climate Change. IPCC, Geneva, Switzerland

Palosuo T, Heikkinen J, Regina K (2016) Method for estimating soil carbon stock changes in Finnish mineral cropland and grassland soils. 
Carbon Manag 6:207-220. https://doi.org/10.1080/17583004. 2015.1131383

Paustian K, Lehmann J, Ogle S et al (2016) Climate-smart soils. Nature 532:49-57. https://doi.org/10.1038/nature17174

Peltoniemi M, Palosuo T, Monni S, Mäkipää R (2006) Factors affecting the uncertainty of sinks and stocks of carbon in Finnish forests soils and vegetation. For Ecol Manag 232:75-85. https://doi.org/ 10.1016/j.foreco.2006.05.045

Peltoniemi M, Thürig E, Ogle S et al (2007) Models in country scale carbon accounting of forest soils

Petersen BM, Knudsen MT, Hermansen JE, Halberg N (2013) An approach to include soil carbon changes in life cycle assessments. J Clean Prod 52:217-224. https://doi.org/10.1016/j.jclepro.2013. 03.007

Reap J, Roman F, Duncan S, Bras B (2008) A survey of unresolved problems in life cycle assessment. Int J Life Cycle Assess 13:374. https://doi.org/10.1007/s11367-008-0009-9

Riggers C, Poeplau C, Don A et al (2019) Multi-model ensemble improved the prediction of trends in soil organic carbon stocks in German croplands. Geoderma 345:17-30. https://doi.org/10. 1016/j.geoderma.2019.03.014

Röös E, Sundberg C, Hansson PA (2011) Uncertainties in the carbon footprint of refined wheat products: a case study on Swedish pasta. Int J Life Cycle Assess 16:338. https://doi.org/10.1007/ s11367-011-0270-1

Saarinen M, Sinkko T, Joensuu K et al (2014) Nutrition and soil quality impacts in life cycle assessment of food (in Finnish). SustFoodChoice-project final report. MTT Report 186

Saarinen M, Kaljonen M, Niemi J et al (2019) Ruokavaliomuutoksen vaikutukset ja muutosta tukevat politiikkayhdistelmät. RuokaMinimi-hankkeen loppuraportti. Valtioneuvoston Selv- Ja Tutkimustoiminnan Julk 2019:160

Sanderman J, Baldock JA (2010) Accounting for soil carbon sequestration in national inventories: a soil scientist's perspective. Environ Res Lett 5:034003. https://doi.org/10.1088/1748-9326/5/3/034003

Schlesinger WH, Amundson R (2019) Managing for soil carbon sequestration: Let's get realistic. Glob Change Biol 25:386-389. https:// doi.org/10.1111/gcb.14478

Sevenster M, Luo Z, Eady S, Grant T (2019) Including long-term soil organic carbon changes in life cycle assessment of agricultural products. Int J Life Cycle Assess. https://doi.org/10.1007/ s11367-019-01660-4

Shi Z, Crowell S, Luo Y, Moore B (2018) Model structures amplify uncertainty in predicted soil carbon responses to climate change. Nat Commun 9:1-11. https://doi.org/10.1038/ s41467-018-04526-9
Smith P, Soussana J-F, Angers D et al (2020) How to measure, report and verify soil carbon change to realize the potential of soil carbon sequestration for atmospheric greenhouse gas removal. Glob Change Biol 26:219-241. https://doi.org/10.1111/gcb.14815

Soimakallio S, Cowie A, Brandão M et al (2015) Attributional life cycle assessment: is a land-use baseline necessary? Int J Life Cycle Assess 20:1364-1375. https://doi.org/10.1007/s11367-015-0947-y

Stanley PL, Rowntree JE, Beede DK et al (2018) Impacts of soil carbon sequestration on life cycle greenhouse gas emissions in Midwestern USA beef finishing systems. Agric Syst 162:249-258. https:// doi.org/10.1016/j.agsy.2018.02.003

Statistics Finland (2019) Greenhouse Gas Emissions in Finland 1990 2017. National Inventory Report Under the UNFCCC and the Kyoto Protocol

Thum T, Nabel JEMS, Tsuruta A et al (2020) Evaluating two soil carbon models within the global land surface model JSBACH using surface and spaceborne observations of atmospheric $\mathrm{CO}_{2}$. Biogeosciences 17:5721-5743. https://doi.org/10.5194/bg-17-5721-2020

Tuomi M, Rasinmäki J, Repo A et al (2011) Soil carbon model Yasso07 graphical user interface. Environ Model Softw 26:1358-1362. https://doi.org/10.1016/j.envsoft.2011.05.009

Tuomi M, Thum T, Järvinen H et al (2009) Leaf litter decompositionEstimates of global variability based on Yasso07 model. Ecol Model 220:3362-3371. https://doi.org/10.1016/j.ecolmodel.2009. 05.016

van Middelaar CE, Cederberg C, Gerber PJ et al (2016) The importance of a life cycle approach for valuing carbon sequestration. In: Book of Abstracts of the 10th international conference on Life Cycle Assessment of Food

Vilja-alan yhteistyöryhmä (VYR) (2011) Vinkkejä erityyppisten vehnien viljelyyn (Tips or the cultivation of different types of wheat)

VTT Technical Research Centre of Finland (2017) LIPASTO unit emissions database. Average emissions and energy use of working machines per fuel in Finland in 2016

Yara (2015) The carbon footprint of fertilizers. http://yara.com/doc/ 29413_Yara_carbon_life_cycle.pdf

Zickfeld K, Azevedo D, Mathesius S, Matthews HD (2021) Asymmetry in the climate-carbon cycle response to positive and negative $\mathrm{CO} 2$ emissions. Nat Clim Change 11:613-617. https://doi.org/10.1038/ s41558-021-01061-2

Zomer RJ, Bossio DA, Sommer R, Verchot LV (2017) Global Sequestration Potential of Increased Organic Carbon in Cropland Soils. Sci Rep 7:1-8. https://doi.org/10.1038/s41598-017-15794-8

Publisher's Note Springer Nature remains neutral with regard to jurisdictional claims in published maps and institutional affiliations. 